University of Nebraska - Lincoln

DigitalCommons@University of Nebraska - Lincoln

Sociology Department, Faculty Publications

Sociology, Department of

2010

\title{
The New Homelessness Revisited
}

Barrett A. Lee

Pennsylvania State University, bal6@psu.edu

Kimberly A. Tyler

University of Nebraska-Lincoln, kim@ktresearch.net

James D. Wright

University of Central Florida, jwright@mail.ucf.edu

Follow this and additional works at: https://digitalcommons.unl.edu/sociologyfacpub

Part of the Sociology Commons

Lee, Barrett A.; Tyler, Kimberly A.; and Wright, James D., "The New Homelessness Revisited" (2010). Sociology Department, Faculty Publications. 127.

https://digitalcommons.unl.edu/sociologyfacpub/127

This Article is brought to you for free and open access by the Sociology, Department of at DigitalCommons@University of Nebraska - Lincoln. It has been accepted for inclusion in Sociology Department, Faculty Publications by an authorized administrator of DigitalCommons@University of Nebraska - Lincoln. 


\title{
The New Homelessness Revisited
}

\author{
Barrett A. Lee, ${ }^{1}$ Kimberly A. Tyler, ${ }^{2}$ and James D. Wright ${ }^{3}$
}

1. Department of Sociology, The Pennsylvania State University, University Park, Pennsylvania 16802-6207; email bal6@psu.edu

2. Department of Sociology, University of Nebraska-Lincoln, Lincoln, Nebraska 68588-0324; email ktyler2@unl.edu

3. Department of Sociology, University of Central Florida, Orlando, Florida 32816-1360; email jwright@mail.ucf.edu

\begin{abstract}
The new homelessness has drawn sustained attention from scholars over the past three decades. Definitional inconsistencies and data limitations rendered early work during this period largely speculative in nature. Thanks to conceptual, theoretical, and methodological progress, however, the research literature now provides a fuller understanding of homelessness. Contributions by sociologists and other social scientists since the mid-1990s differentiate among types of homelessness, provide credible demographic estimates, and show how being homeless affects a person's life chances and coping strategies. Agreement also exists about the main macro- and micro-level causes of homelessness. Active lines of inquiry examine public, media, and governmental responses to the problem as well as homeless people's efforts to mobilize on their own behalf. Despite the obstacles faced when studying a stigmatized population marked by high turnover and weak anchors to place, recent investigations have significantly influenced homelessness policy. A greater emphasis on prevention should further strengthen the research-policy nexus.
\end{abstract}

\section{Keywords}

homeless population, poverty, housing, disaffiliation, social exclusion, public policy, causes and consequences of homelessness 


\section{Introduction}

The study of homelessness enjoys a rich tradition in American sociology, spanning the tramp (1890s-1920s), Great Depression (1930s), and skid row (1940s-1970s) eras. Our focus here is scholarly work on the new homelessness from 1980 through the present. Soon after this latest era began, opinion polls ranked homelessness among the nation's top domestic problems. Research activity accelerated, prompting an $A n$ nual Review article by Shlay \& Rossi in 1992. The authors discussed what had been learned about the number and attributes of homeless persons and the factors responsible for the rise in homelessness. Given the material available, their review emphasized descriptive findings and drew heavily from a fugitive literature issued by government agencies, research institutes, and advocacy organizations.

Although popular attention to homelessness has waned since the early 1990s, the current economic downturn and housing crisis are once again bringing the issue to the fore. Interest continues to be high among social scientists (Buck et al. 2004), owing to the entrenched nature of the phenomenon and to awareness of the many individuals at risk of becoming homeless. Intellectually, visible homeless people-those in shelters or on the streets - are attractive subjects because they lead their lives in the open, rendering social processes observable. They also constitute valuable extreme cases with which to test general (nonhomeless-specific) theories and hypotheses (see, e.g., Entner Wright 1998, Lee et al. 2004, McCarthy \& Hagan 2005).

For sociologists, homelessness bears on core issues in stratification and methodology. Homeless persons anchor the low end of a vast and growing wealth disparity in the United States. While they share manifestations of disadvantage (such as health deficits and exposure to crime) with their nonhomeless but impoverished counterparts, the homeless are qualitatively different in many respects. Most obvious is their lack of permanent residence, which makes their marginality visible to all. That marginality in turn poses the challenge of how best to study a fluid, stigmatized, and sometimes inaccessible group. Although recent investigations tend to be more sophisticated than those covered by Shlay \& Rossi (1992), our knowledge of homelessness remains tentative. This has encouraged alternative constructions of homelessness, varied public reactions, and lively policy debates.

Because of the volume of post-1990 literature, attempting an exhaustive review is futile. Hence, we give priority to sociological inquiries (recognizing research from other disciplines as appropriate) and to published work over agency reports. Topically, we focus on $(a)$ conceptual questions surrounding homelessness; (b) homeless population size, composition, and distribution; $(c)$ homeless people's life chances; $(d)$ coping strategies employed to meet basic needs; (e) explanations for homelessness; $(f)$ public views and media coverage; and $(g)$ actions taken to address homelessness. In each of these areas, significant advances are evident since Shlay \& Rossi's review. We conclude with a brief consideration of the relationship between homelessness research and policy and the kinds of steps needed to insure the relevance of the former to the latter.

\section{Conceptualizing Homelessness}

Intuitively, homelessness involves a lack of housing. During the tramp and skid row eras, however, sociologists emphasized one's position in society. Single male occupants of inexpensive hotels and lodging houses were considered homeless if they had few social attachments, moved frequently, or drank heavily (Bahr \& Caplow 1974). These indicators of disaffiliation have become less common as a definition of homelessness because of their historically and culturally specific notions about normal statuses and behaviors. A more practical hurdle is the detailed data required to operationalize homelessness as disaffiliation.

Contemporary definitions stress housing hardship linked to extreme poverty. The poverty component, though implicit, is fundamen- 
tal: Affluent individuals who unexpectedly lose their housing (to fire, flood, and the like) can replace it quickly and avoid a prolonged homeless episode. Many studies have followed Rossi $(1989$, p. 10) in defining homelessness as "not having customary and regular access to a conventional dwelling." The McKinney-Vento Homeless Assistance Act, a key piece of federal legislation, offers a housing-based definition similar to Rossi's that refers to the absence of an adequate nighttime residence but also specifies physical presence in selected locations shelters, institutional settings, and places not intended for human habitation - as a sufficient condition to establish one's homelessness.

These literal without-housing definitions appear straightforward at first. Street venues such as sidewalks, subway tunnels, and airport terminals are clearly not designed for sleeping despite their routine use as makeshift accommodations (Dordick 1997, Hopper 2003). Other venues are more ambiguous: Should people squatting in abandoned apartment buildings or those temporarily staying in cheap hotels be counted as homeless? Even the meaning of shelter is unclear. Experts disagree, for example, over what to do about persons in domestic violence facilities, residential treatment programs, and transitional housing for the mentally ill. Although housing-oriented approaches promise greater precision and practicality than does the concept of disaffiliation, ambiguity persists.

The temporal dimension must also be addressed. An important recent insight is that patterns of time spent outside of conventional housing vary significantly. Three major types of homelessness have been documented based on these patterns: (a) transitional or temporary, describing individuals who are in transition between stable housing situations and whose brief homeless spells often amount to once-in-a-lifetime events; $(b)$ episodic, which entails cycling in and out of homelessness over short periods; and $(c)$ chronic, which approximates a permanent condition (Culhane et al. 2007). The chronically homeless are overrepresented in crosssectional investigations, yet many more people experience transitional and episodic homelessness, given the higher turnover rates.

A fine line separates some portions of the literal homeless population from precariously or marginally housed persons, who are at varying risk of becoming homeless. Among the more secure are those in dwellings of their own who labor under heavy rent-to-income burdens (Myers \& Wolch 1995). Others live in trailers or recreational vehicles, enjoying a measure of privacy and safety, but may not control the land on which they are parked (Salamon \& MacTavish 2006, Wakin 2005). Individuals doubled up in conventional housing with relatives or friends are often treated as a hidden homeless population (Entner Wright et al. 1998, Link et al. 1995a). More generally, all three of these precariously housed groups resemble the episodically or transitionally homeless in terms of their residential instability. They thus reinforce the point that housing hardship forms a continuum not easily dichotomized into homeless and nonhomeless segments.

\section{Homeless Demography}

The most common questions about the homeless concern numbers, composition, and geographic distribution. In the Shlay \& Rossi (1992) review, however, definitive answers were rare. With a few exceptions, empirical work during the 1980s suffered from inconsistent definitions, limited samples, indirect measurement (relying on informant reports, bed counts, or heroic assumptions about street-to-shelter ratios), and other serious flaws. Such problems have spurred technical improvements and explicit attention to how aspects of research design shape results.

Recent methodological advances do not mean that the demographic description of homelessness is now straightforward. Attempts to produce a nationwide point estimate of the number of homeless are instructive. Against the backdrop of earlier estimates ranging from 250,000 to nearly 3 million homeless (discussed 
in Shlay \& Rossi 1992), the Census Bureau invested substantial resources in its 1990 S-night (street and shelter) operation. Employing direct observation, S-night staff tallied 228,000 to 240,000 individuals (the number contingent on whether domestic violence shelter occupants were included) during the evening and early morning hours of March 20-21, 1990 (Wright \& Devine 1992).

This total, decried by advocates as far too low, was challenged by independent, Censusfunded evaluations in five selected cities that documented street enumerators failing to show up at predesignated sites, approaching only certain persons for interviews, and otherwise departing from protocol (Wright \& Devine 1992). An intensive police and media presence, coupled with an uncountable group of homeless individuals beyond the intended reach of S-night (Wright \& Devine 1995), further increased worries about a gross underestimate of the street population. In response, Congress banned the usage of S-night data for programmatic purposes. Census efforts in 2000 fared little better; the Bureau's hesitation to fully release results from its service-based enumeration drew official criticism.

Two other government-sponsored undertakings have yielded more credible point estimates. The National Survey of Homeless Assistance Providers and Clients (NSHAPC) features a multistage probability sample representative of all homeless people who used homeless-targeted services during the fall of 1996 (Burt et al. 2001). Because most homeless, sheltered or otherwise, come in contact with some aspect of the service infrastructure, the population coverage achieved by NSHAPC should be reasonably complete, though less so in smaller communities with fewer services. NSHAPC estimates suggest average daily and weekly populations of 267,000 and 440,000 , respectively, inclusive of homeless service consumers and their accompanying children. The most current national figures available are U.S. Department of Housing and Urban Development (HUD) compilations of the single-day counts required of local Continuum of Care
(CoC) agencies as part of their federal funding applications. For January 2008, local CoC counts sum to a one-day total of approximately 665,000 homeless (U.S. HUD 2009). Significantly, neither the HUD nor the NSHAPC data offer any evidence of a decline in the size of the U.S. homeless population when compared with the soundest estimates from the 1980s, despite efforts to address the problem.

Period prevalence measures constitute an attractive alternative to the point estimation approach. These measures, which indicate how many different individuals have been homeless in a particular time interval, are more sensitive to transitional and episodic forms of homelessness. Their value was first demonstrated by Culhane and associates (1994) with administrative databases (containing client intake interview and discharge/reentry information) for the Philadelphia and New York shelter systems. In both cities, roughly $1 \%$ of all residents spent a night or more in a shelter during 1992; for the preceding three-year (Philadelphia) and five-year (New York) periods, the rate was close to $3 \%$. At HUD's prompting, similar databases are being implemented throughout the United States. Collectively, they suggest that at least 1.6 million Americans use a shelter or transitional housing program annually (U.S. HUD 2009). Excluded from this estimate are homeless persons who do not have any shelter contact.

A broader period prevalence study by Link and colleagues (1995a) asked a probability sample of housed adult Americans about past experiences with homelessness. More than $14 \%$ of the respondents (representing 26 million people when appropriately weighted) said that they had been homeless at some time in their lives. Additional evidence from domiciled samples indicates that lifetime prevalence is greater in the United States than in many European countries (Toro et al. 2007) and that American youth-typically excluded from prevalence surveys - exhibit annual rates approaching $8 \%$, with boys much more likely than girls to be homeless during the previous year (Ringwalt et al. 1998). 
Children make up a larger percentage of the homeless today than they did during earlier eras, as do women, families (mostly female-headed), and blacks; the elderly comprise a smaller percentage (Dennis et al. 2007, Fosberg \& Dennis 1999, Hopper 2003, Wright et al. 1998). Even compared with the U.S. total and poverty populations, blacks are overrepresented among the homeless (Burt et al. 2001, U.S. HUD 2009). What stands out now, as in the past, is that single men constitute the mode, a pattern perhaps exaggerated by reliance on cross-sectional surveys that disproportionately capture the chronically homeless. One careful analysis of local prevalence rates lends credence to this possibility, finding a higher annual risk of sheltered homelessness among young children (under age 5) than among men (Culhane \& Metraux 1999),

Clearly, the homeless are not a monolithic or homogeneous group. Homeless men and women, for example, have different characteristics, both inside and outside of families (Burt et al. 2001). Demographic composition also depends on context, with distinct profiles evident for street and shelter settings and across communities. Los Angeles provides an apt illustration; it has a greater share of Hispanic homeless persons than does the nation as a whole, calling into question the paradox of infrequent homelessness among Latinos (Conroy \& Heer 2003). In general, the racial and ethnic mix of a local homeless population reflects that of the surrounding community.

Although homelessness can be found in rural settings (Robertson et al. 2007), it is much more common within the metropolis, where downtown redevelopment, gentrification, the closure of single-room occupancy hotels, and shelter relocation have produced an uneven distribution of homeless people (Lee \& Farrell 2005). Approximately one-fifth of all homeless are now found in suburbs (Burt et al. 2001, Lee \& Price-Spratlen 2004). Others have recongregated in a handful of niches away from the central business district but inside city limits. These niches feature services, mixed land uses, access to transportation, a tolerant atmosphere, and related elements of what Duneier (1999) terms a sustaining habitat. Combined with remnant skid row infrastructure, such locations form a larger polynucleated pattern (Lee \& PriceSpratlen 2004). Yet the particulars of polynucleation, as with any homeless geographic distribution, are not permanent, given the tenuous anchors of homeless persons to place.

\section{Life Chances}

The relegation of the homeless to a limited number of niches is a spatial manifestation of their more general marginality. This marginality in turn reflects life chances, the ability to benefit from the opportunities while avoiding the pitfalls offered by society. Because many homeless face challenges in health and other life domains, it is tempting to treat any deficits in these areas (e.g., mental illness) as antecedents of homelessness. But deficits can just as readily be outcomes produced or exacerbated by street and shelter existence. While we touch on such causal complexities here, our primary objective is to evaluate homeless people's life chances in three vital domains - material well-being, physical and mental health, and safety - for which new evidence has accumulated since Shlay \& Rossi (1992) published their review.

Evidence on material well-being underscores the extreme deprivation of the homeless. NSHAPC documents a median monthly income of roughly $\$ 300$, with $13 \%$ of all respondents reporting no income from any source during the previous month (Burt et al. 2001). Single homeless persons, especially men, are the worst off; they earn only meager wages from work and are ineligible for benefit programs that favor families. Relatively few homeless adults receive benefits other than food stamps, and many who are disabled do not receive Supplemental Security Income or similar payments (Burt et al. 2001, Wright et al. 1998). Homeless children suffer from their parents' poverty, as evidenced by more frequent school mobility, absenteeism, and grade retention; lower achievement test scores; and a 
greater risk of learning disabilities, behavioral disorders, and related problems than their domiciled peers (Rafferty et al. 2004, Zima et al. 1997). These educational deficits increase the odds of future disadvantage in adulthood.

Homeless persons of all ages differ dramatically from domiciled Americans in health. Food insecurity and nutritional problems persist among the homeless despite a major expansion of meal programs since the mid-1980s (Dachner \& Tarasuk 2002, Lee \& Greif 2008). Tuberculosis, HIV/AIDS, hepatitis, hypertension, peripheral vascular disease, seizures, and most other infectious and chronic conditions are also more prevalent in homeless than in domiciled populations, by factors ranging from 2 to 20 (Culhane et al. 2001, Haddad et al. 2005, Szerlip \& Szerlip 2002). A disproportionate share of the homeless have histories of alcohol or drug abuse (Burt et al. 2001, Dennis et al. 1999), which in turn create or amplify physical health problems.

Substance abuse regularly co-occurs with mental disorders (Dennis et al. 1999, Reardon et al. 2003). According to NSHAPC data, onethird of all homeless individuals exhibit some combination of alcohol/drug and mental health problems during the past year (Burt et al. 2001). Mental illness alone may afflict 30\% to $40 \%$. Although the prevalence of serious mental illness is still disputed, homeless people's life circumstances are associated with elevated levels of depression and suicidal ideation (Bao et al. 2000, Fitzpatrick et al. 2007). Mental health disorders are significantly more common among the homeless than among the public at large, even after taking the possible overdiagnosis of some disorders into account.

Most health problems are distributed unevenly within the homeless population (see, e.g., Dietz 2007, Lee \& Greif 2008). Problems that vary by race, gender, or age in housed samples usually do so among the homeless. Type of homelessness also matters. The chronic subgroup is the least healthy, presumably because prolonged homelessness harms health via stress, exposure, crowding in shelters, dietary and hygienic shortcomings-or complicates the delivery of medical care (Kushel et al. 2001, Wright 1990). Alternatively, poor health can cause homelessness if it interferes with employment, reduces income, or ruptures social ties.

Such linkages between homelessness and health culminate in excessive mortality. Studies that generate standard mortality ratios for service-using cohorts of homeless people reveal age-adjusted death rates two to four times higher than in domiciled comparison populations, with the average age at death falling in the low 40s to mid-50s. Chronic and infectious disease, traumatic injury, and homicide/suicide rank among the most common causes of death, and substance abuse and long durations of homelessness appear to increase mortality risk (Hwang et al. 1998, O'Connell 2005).

Safety is another domain that illustrates the reduced life chances of homeless people. Without a dwelling of their own, the homeless find it difficult to secure themselves or their belongings. Despite pressures toward underreporting (because of embarrassment, an inability to document incidents, and the like), over one-half of all homeless NSHAPC respondents say that they have been victims of crime, primarily theft but also beatings and sexual assault (Burt et al. 2001, Lee \& Schreck 2005). Results from other studies demonstrate substantial victimization rates for homeless women, youth, seniors, and shelter occupants (Dietz \& Wright 2005, Tyler et al. 2004, Wenzel et al. 2001). Fear and vicarious victimization (witnessing or hearing about crime) are widespread as well (Fitzpatrick et al. 1999, Kipke et al. 1997).

The likelihood of being victimized is increased by neglect or violence in childhood, long episodes of homelessness, involvement in street activities, substance use, and poor health (Hoyt et al. 1999, Lee \& Schreck 2005, Tyler et al. 2001, Wenzel et al. 2001). Homeless persons are easy marks for domiciled predators and unscrupulous business operators (e.g., labor contractors who withhold pay, liquor store clerks who overcharge), but they also victimize each other. Close physical proximity, limited guardianship, retaliation, preemptive displays of toughness, and a low probability of sanctions are condu- 
cive to homeless-on-homeless crime. In general, street and shelter settings give rise to a vicious cycle in which some homeless people alternate between victim and offender roles (Baron \& Hartnagel 1998, Tyler \& Johnson 2004).

\section{Coping Strategies}

It is easy to imagine how homeless people could feel overwhelmed by their difficult circumstances. Nevertheless, recent researchprimarily ethnographic in nature-portrays many homeless as active decision-makers who weigh the benefits and costs of alternative strategies for meeting basic needs (Dordick 1997, Entner Wright 1998, Molina 2000, Snow \& Anderson 1993, Wagner 1993). Their decisions, like those of their domiciled counterparts, may not always be perfect, but even seemingly peculiar courses of action prove understandable once the limited options available are recognized. Because they face such serious constraints, the homeless must excel at improvisation, coping through creative, opportunistic, and varied means.

One instrumental coping strategy is to take advantage of shelters, soup kitchens, and other homeless services. Shelters in particular are critical because they can be counted on for rudimentary sustenance. Whether they offer less tangible resources-safety, stimulation, companionship, freedom - is an open question. According to Grunberg \& Eagle's (1990) shelterization thesis (distilled from observations at a large armory in New York City), shelter residence encourages passivity and dependency, weakening clients' drive to escape homelessness as shelter-dwelling peers become their reference group. Critics contend that the shelterization thesis neglects the permeability of boundaries: Individuals spend time outside as well as inside shelters, and their stays are usually short (Armaline 2005, Marcus 2003). Thus, the shelter effect proposed by the thesis may be overstated.

Implicit in the thesis is the erroneous assumption that homeless persons have uniform shelter experiences. The hierarchical organization of the shelter, for example, is felt by residents to a greater or lesser degree, contingent on how staff enforces rules (Dordick 1997, Liebow 1993). Even when the rules are intended to be therapeutic, their implementation can backfire. Shelter users worried about expulsion may attempt to curry favor with staff or shun contact with fellow clients, out of fear of snitching (Dordick 1997). Others resist via subtle acts of disobedience and forceful objections to treatment perceived as unfair or demeaning (Wagner 1993, Williams 2003). In general, ethnographic studies show the social order of shelters and similar services to be negotiated through client-staff interaction rather than unilaterally imposed (Armaline 2005, Sager \& Stephens 2005).

Outside of shelters, homeless people attempt to earn a living in myriad ways. Regular work in the formal economy is preferred but hard to come by. Among the barriers are checkered employment histories, clothing and transportation requirements, and-most fundamentally-poor job skills (Snow \& Anderson 1993). Hence, participation in the formal economy is often through temporary or day labor, which features low wages, no benefits, irregular hours, and occasionally unsafe conditions (Kerr \& Dole 2005). For homeless youth, however, even menial employment has been found to serve as an escape route, providing rewards and commitments that reduce the appeal of street life (Hagan \& McCarthy 1998, Karabanow 2008).

Because of the obstacles to normal work, Snow \& Anderson (1993) hypothesize that many individuals turn to shadow work as their duration of homelessness increases. Shadow work comprises resource-generating efforts outside the formal economy, including scavenging, panhandling, recycling, bartering, street vending, plasma donation, and illegal acts such as theft, prostitution, and drug sales (Duneier 1999, Hagan \& McCarthy 1998, Lee \& Farrell 2003). Most forms of shadow work have a low skill threshold, yet they give practitioners a sense of control and self-respect, not to mention 
an outlet for entrepreneurial impulses. There are, of course, problematic aspects to shadow work, which can be dirty, dangerous, physically taxing, and unreliable as an income source. Moreover, community settings differ in receptivity: Certain shadow activities are strictly regulated or criminalized.

The difficulties encountered in satisfying essential needs hint at the survival value of personal networks. Self-reports from local surveys indicate that a surprising number of homeless people stay in touch, albeit sporadically, with domiciled family members and friends (Johnson et al. 2005, LaGory et al. 1991, Toohey et al. 2004). In many instances, though, a homeless person's significant others are impoverished themselves, less able to lend material than emotional support. Kin and friendship ties can be further strained by past occurrences of abuse, addiction, and conflict.

Consequently, homeless peers represent an attractive, accessible alternative to relations with the domiciled. Peer networks differ in size, strength, and content: The mentally ill homeless, for example, frequently have sparse networks, and ties to deviant peers tend to expose one to risky behaviors (Hawkins \& Abrams 2007, Rice et al. 2005, Tyler 2008, Whitbeck \& Hoyt 1999). Yet much qualitative and quantitative evidence suggests that social relationships among the homeless, ranging from casual acquaintances to street families, register beneficial effects (Dordick 1997, Ennett et al. 1999, Molina 2000, Smith 2008). This optimistic conclusion is consistent with the norms of sharing, reciprocity, and fairness found to govern such relations. Tempering that conclusion are the high levels of turnover, desperation, and distrust in the homeless population, all of which make emergent social solidarity fragile (Liebow 1993, Rosenthal 1994, Snow \& Anderson 1993).

Despite their ambiguous character, social relations with homeless peers pay instrumental dividends over the short run, helping a person secure food, income, and other resources. They can also be used to address threats to psychological well-being. Homeless people are well aware of the negative traits imputed to them-lazy, filthy, irresponsible, dangerous - based on the homeless label (Anderson et al. 1994, Kidd 2007, Phelan et al. 1997). The stigma associated with homelessness is reinforced through the visibility of the condition and the reactions of housed individuals who ignore the homeless or subject them to stares, verbal harassment, or violence (Anderson et al. 1994, Lankenau 1999a).

One method to address a stigmatized status is to seek fellow homeless travelers for nonjudgmental socializing. Conversations among the homeless often consist of what Anderson and associates (1994, p. 128) term identity talk, in which participants "construct and negotiate personal identities, consistently casting themselves in positive ways." Because their claims are rarely challenged by peers, homeless persons may engage in fictive storytelling without fear. Some try to distance themselves from other stigmatized groups, including certain undesirable categories of homeless, through verbal denigration or invidious comparison (Roschelle \& Kaufman 2004, Snow \& Anderson 1993).

A spoiled identity is tougher to overcome in the presence of the domiciled. This has led to the development of an extensive repertoire of identity management techniques that require the manipulation of setting, appearance, and demeanor. Ethnographic investigations across a range of settings describe attempts by homeless adults and youth to hide out, cover (i.e., make one's stigma less obvious), pass as housed, maintain emotional control, and establish bridging relationships with the nonhomeless (Anderson et al. 1994, Lankenau 1999b, Roschelle \& Kaufman 2004). Displays of defiance or aggression appear less common owing to their counterproductive nature. Some homeless voluntarily embrace their status, finding virtue rather than shame in otherness. Threats to identity may also be countered by lowered aspirations, a fatalistic outlook, alcohol and drug use, and the creation of alternative realities (Cohen \& Koegel 1996, Liebow 1993, Snow \& Anderson 1993). 
The long-term implications of these coping mechanisms are a matter of debate. To the extent that the mechanisms render street and shelter life both bearable and meaningful, they could facilitate an adaptation to homelessness that reduces the odds of escape (Dordick 1997, Snow \& Anderson 1993). Pressures to satisfy immediate needs might further work against the kind of goal-setting critical to such escape. Remember, though, that the vast majority of homeless people avoid becoming chronically homeless. Most are quite motivated to exit, given their housed backgrounds and socialization into a dominant culture that equates shelter with worth (Rosenthal 1994). Indeed, Entner Wright's (1998) analysis of multiwave survey data from Minneapolis finds that those individuals who explicitly plan to exit homelessness are more likely to do so than nonplanners.

\section{What Causes Homelessness?}

Disciplinary and ideological arguments over the causes of homelessness have diminished since Shlay \& Rossi assessed the 1980s literature. Among researchers, rough agreement now exists on a conceptual model that integrates macro- and micro-level antecedents (Jencks 1994, Koegel et al. 1996, O'Flaherty 1996). The macro portion of the model emphasizes structural forces that generate a population of poor people at risk of homelessness. The micro portion considers how certain members of that atrisk population become homeless because of their personal vulnerabilities, institutional experiences, and inadequate buffers. Situational crises (i.e., bad luck) are also acknowledged though less often documented (Snow \& Anderson 1993). In short, the macro/micro model encourages us to view homelessness as a product of what O'Flaherty (2004, p. 1) calls "a conjunction of unfortunate circumstances."

At the macro level, big-picture narratives attribute homelessness to the housing squeeze (an excess of affordable housing demand over supply), economic conditions (e.g., restructuring, joblessness, poverty), demographic trends (competition within the baby boom cohort, more single-person and single-parent households), policy shifts (in welfare, mental health, and housing), and the crack epidemic, among other factors (Blau 1992, Burt 1992, Jencks 1994, Wright et al. 1998). A common empirical approach is to assess the relative importance of such factors by analyzing differences in homeless rates across metropolitan areas. One finding stands out from these studies, all of which preceded the current economic crisis: Rates tend to be greater in areas where access to affordable units (indicated by high rents, few vacancies, etc.) is problematic, consistent with the housing squeeze explanation (Lee et al. 2003, Quigley et al. 2001, Wright et al. 2008).

Caution is advised when interpreting the metro area results, however, given the age and quality of the homelessness rates on which they rest. Moreover, the cross-sectional design of most metro research leaves open the possibility that the rates may be homeless antecedents as well as outcomes, tapping a community's generosity - or advocates' success - in providing shelter beds (O'Flaherty 2003). The failure to satisfactorily measure some macro explanations further challenges the credibility of those that have received support. Countering these concerns is the robust significance of housing and economic variables when homelessness is investigated over time, across neighborhoods, for particular cities, or with multilevel statistical procedures (Culhane et al. 1996, Fertig \& Reingold 2008, Park 2000).

Individuals regularly cite manifestations of structural dislocation such as increased housing costs or lack of work when asked why they are homeless (Burt et al. 2001, Snow \& Anderson 1993). But their pathways into homelessness are inevitably more complicated, a partial reflection of distal and proximate micro-level vulnerabilities. Both qualitative and survey evidence shows that the path for many begins in childhood. Exposure at a young age to physical and sexual abuse, neglect, family conflict, poverty, housing instability, and alcohol and drug use increases the odds of experiencing homelessness (Koegel et al. 1995, Tyler 2006, Yoder 
et al. 2001). Adult risk factors for homelessness are similar, with mental disorder, death of a spouse, and - in the case of women-domestic violence added to the mix (Bassuk et al. 2001, Crane et al. 2005, Jasinski et al. 2010, Shinn et al. 2007).

The stressful nature of structural hard times (high unemployment, a tight housing market, etc.) helps generate personal vulnerabilities and magnify their consequences. In turn, the vulnerabilities reinforce each other, setting the stage for a situational crisis (e.g., illness or injury, a job layoff) to trigger the onset of a homeless spell (Crane et al. 2005, Koegel et al. 1996). Given such a potent and complex combination of influences, the popular notion that many people voluntarily choose homelessness seems doubtful. As Jencks (1994), Snow \& Anderson (1993), and others observe, that choice will be made only when the hardship of street and shelter life is judged more attractive than remaining in a dysfunctional and potentially dangerous domiciled environment.

Personal vulnerabilities may lead to placement in an institutional setting or program. Prospective studies have found that homelessness occurs disproportionately often after discharge from foster care, treatment facilities, and prisons or jails, affecting one-tenth to one-third of the alumni of these institutions (Metraux et al. 2007, Pecora et al. 2006). Reasons for the institution-homelessness linkage are discussed in recent work on incarceration. Former inmates wind up with no place to go because of inadequate prerelease preparation, fragile finances, severed social relationships, and barriers posed by their stigmatized identities when seeking employment and housing (Metraux et al. 2007, Roman \& Travis 2006). Foster \& Hagan (2007) suggest that incarceration can even have intergenerational impacts, elevating the chances of homelessness among inmates' children.

Once again, alternative causal sequences are possible. Homelessness, for example, has been known to prompt or exacerbate problems (e.g., heavy drinking, theft of money or food) that result in institutional engagement (Gowan
2002, Greenberg \& Rosenheck 2008). And, consistent with the logic of social selection, preexisting attributes might be responsible for both engagement and postdischarge homelessness. The role of selection is hinted at in comparisons that document greater lifetime disadvantage among homeless veterans from the all-volunteer era than from the draft era of the military, another type of institution (Tessler et al. 2003).

In contrast to micro variables that push people along the path toward homelessness, buffering factors slow or halt movement in that direction. Among the obvious buffers are ties to nonhomeless relatives and friends, which can be valuable sources of material and emotional aid (Bassuk et al. 1997). However, these ties may prove less useful if one's significant others have few resources to share, behave in ways that make the at-risk individual worse off, or feel that the individual has worn out his or her welcome (Shinn et al. 1991). Support from the service safety net constitutes another kind of buffer. Based on longitudinal investigations of sheltered homeless families and adults and of at-risk but domiciled families, the likelihood of securing or maintaining a permanent residence is boosted significantly by entitlement income, a housing subsidy, and contact with a social worker (Bassuk \& Geller 2006, Dworsky \& Piliavin 2000, Fertig \& Reingold 2008).

Longitudinal surveys, along with administrative data systems that allow people's shelter stays to be tracked, underscore the importance of moving beyond the conception of homelessness as a dichotomous variable. Since 1990, much research has sought to explain different types of homelessness, defined by the frequency and duration of homeless spells (Culhane et al. 2007, Wong 1997). The antecedents of chronic homelessness, as an illustration, include being male, older, single, poorly educated, rarely employed, substance dependent, and lacking family and other supports (Allgood \& Warren 2003, Caton et al. 2005). Once persons who fit this profile enter a chronic state, the coping strategies described earlier would seem to reduce or even eliminate any chance of escape. 
Yet the most striking insight from the longitudinal literature concerns the fluid nature of housing status, with exits from and reentries to homelessness quite common after the initial spell (Metraux \& Culhane 1999, Piliavin et al. 1996, Wong \& Piliavin, 1997). Minorities and persons in stressful family circumstances find it especially hard to avoid the repeated exit-andentry pattern, as do those not caught by the service safety net (see above). Leaving the streets (as distinct from shelters) is also difficult, both for homeless youth and adults, although stages in the exiting process can be discerned (Auerswald \& Eyre 2002, Cohen et al. 1997, Karabanow 2008). The general lesson here is that our causal thinking requires greater sensitivity to homeless dynamics and to the micro and macro influences that shape pathways not only into but through and out of homelessness.

\section{Public And Media Views}

The public's beliefs about the causes of homelessness are important because they can influence behavioral and policy responses to homeless people. National and local surveys show that domiciled respondents recognize multiple causes but tend to emphasize structural forces and bad luck over individual deficits (Lee et al. 1991, Toro \& McDonell 1992). These results suggest a more nuanced understanding of homelessness than of poverty in general, which is usually attributed to personal failings. Members of the public also perceive the characteristics of the homeless in reasonably accurate terms and express as many favorable as unfavorable attitudes toward them (Lee et al. 1991, Toro \& McDonell 1992). On balance, the American public's perspective on homelessness appears sympathetic - albeit to a lesser degree than their European counterparts (Toro et al. 2007) - and has remained so over time (Link et al. 1995b).

Not everyone regards homelessness in a sympathetic light, of course. Whites, males, and political conservatives are more likely to believe in individual causes, hold negative opinions, and endorse restrictive measures to address the problem (Lee et al. 1991, 2004; Toro \& McDonell 1992). Education has a mixed impact, boosting tolerant attitudes toward the homeless while reducing support for economic assistance (Phelan et al. 1995). Virtually any kind of exposure to homelessness-observing homeless persons, living in a community with a homeless presence, or having experienced homelessness oneself - has been found to erode stereotypes and render attitudes more positive (Knecht \& Martinez 2009; Lee et al. 1991, 2004; Toro et al. 2007). However, sympathetic attitudes may turn hostile if shelters or services are about to be sited next door.

For most people, knowledge of homelessness comes from less proximate sources. Recent research in the constructionist tradition focuses on the news media, given their pivotal role as framers of social problems. Despite variation in the media outlets and time periods investigated, several generalizations about homelessness coverage have emerged. The volume of coverage, for example, follows an annual cycle, cresting during the holiday season as an expression of ritualized concern for the unfortunate (Buck et al. 2004, Bunis et al. 1996, Shields 2001). Over the longer term, coverage has declined markedly since the peak year of 1987, although it remains higher than it was prior to 1980 (Buck et al. 2004).

A notable trend is also apparent in the content of coverage. News stories during the early 1980s portrayed the homeless as a diverse group challenged by circumstances beyond their control and hence deserving of aid (Lee et al. 1991, Pascale 2005, Spencer 1996). This positive picture has given way to somewhat harsher coverage over the past two decades, with more stories on the deviance of homeless persons, the disorder they create, and the steps being taken to deal with them (Buck et al. 2004, Pascale 2005, Shields 2001). Similarly, empirical conclusions about the size of the homeless population often lose out to sensationalistic guesstimates (Hewitt 1996). These peculiarities in coverage - at odds with the public's rather sophisticated views could be a function of journalists' need to select 
among competing topics and then to craft a narrative with sufficient novelty to hold consumer interest. Other applications of the constructionist approach have considered a wider range of actors (Bogard 2003).

\section{Taking Action}

Regardless of how homelessness is socially constructed, agreement exists that something needs to be done about it. But what? The national policy debate has varied over time, with an initial emphasis on emergency services during the 1980s morphing into the current campaign to permanently house individuals who experience chronic homelessness. Steps taken to address the problem vary from one community to the next as well. Even within a community, divergent agendas may be pursued, seeking either to improve the lot of homeless people or to punish or exclude them. Here we examine selected responses to homelessness that have received substantial attention from scholars since the publication of Shlay \& Rossi's review.

Homeless persons would appear to face significant barriers to mobilization. Nevertheless, case studies and archival research document their engagement in all manner of protest events, especially in cities marked by expensive housing, large-scale redevelopment, or widespread unemployment and poverty (Rosenthal 1994, Snow \& Mulcahy 2001, Snow et al. 2005, Wright 1997). From a strategic standpoint, the homeless may increase their political leverage by joining forces with housed advocates in prohomeless social movement organizations. Organizational viability is contingent on strong leadership and the procurement of resources, often through the cultivation of benefactor relationships (Cress \& Snow 1996). Some homeless, however, prefer spontaneous protest to more conventional political activity and grow suspicious when mobilization becomes bureaucratized (Wagner 1993).

Under the right conditions, significant accomplishments are possible. Cress \& Snow's (2000) comparative analysis of 15 homeless movement organizations finds that-assuming an adequate resource base - such organizations stand a better chance of success if they can adeptly frame their major issues, attract support from influential community members, and finetune their tactics to the local context, negotiating with government officials or threatening to embarrass them as need be. This combination of factors has produced intended outcomes in a number of cities, where homeless people and their allies have secured rights (e.g., to vote or attend school), reduced harassment, expanded housing opportunities, and improved access to services (Cress \& Snow 2000, Rosenthal 1994, Wright 1997).

Beyond concrete collective gains, less tangible individual benefits accrue. Fieldwork indicates that the most politically engaged homeless express newfound confidence and empowerment and acquire information and social capital as a result of their activism (Wagner \& Cohen 1991, Wright 1997). They are also more likely than their less engaged counterparts to exit homelessness, creating a perpetual leadership shortage that makes sustained progress difficult. Homeless activists who stay committed to the cause risk having their voices muted in another way. Should they wind up on task forces or coalitions, disagreements among the dominant members-government representatives, business leaders, and service providers - frequently prompt compromises that justify current practices (Croteau \& Hicks 2003). These suggestive conclusions about the mobilization experiences of homeless people await the accumulation of evidence for more settings and time periods.

Any attempt to change a community's response to homelessness can ignite fierce opposition, as research on shelter location decisions attests. Historically, shelters have been concentrated in depressed inner-city districts, but downtown revitalization pressures have spurred attempts to decentralize these facilities (Brinegar 2003, Lee \& Farrell 2005). Decentralization proposals are endorsed by residents of poor neighborhoods, who argue that their areas constitute dumping grounds already saturated with undesirable service sites. In contrast, 
inhabitants of outlying urban and suburban neighborhoods tend to object vigorously to shelter relocation plans. Their NIMBY (not in my backyard) reactions become even stronger if a few vocal neighbors arouse fears over the impact of a shelter on property values, safety, and public health (Dear 1992). The implicit concern is that the stigma associated with homelessness may infect their neighborhood (Takahashi 1998).

Employing litigation, zoning regulations, and other measures, middle-class residents have been effective in keeping shelters at a distance. One consequence is that the suburban and rural homeless are forced to the urban core for services. Another consequence is that regional and municipal governments must justify their locational policies more carefully. In New York City, for example, the decentralization of shelters has been presented as a move toward greater equity across communities (Gaber 1996). If, on the other hand, local officials continue to shield well-to-do neighborhoods from homeless facilities, advocacy organizations can seek federal intervention via housing discrimination laws; Oakley (2002) analyzes such an instance in Albany, NY. NIMBYism may also be overcome through enhanced shelter design. Although recent evidence suggests a nontrivial spatial dispersion of homeless shelters, the host neighborhoods remain disproportionately disadvantaged (Lee \& Farrell 2005).

Negative reactions to the homeless emanate not only from the metropolitan periphery. The presence of homeless people in downtown public spaces has led an increasing number of cities to criminalize homelessness, defining normal behaviors-eating, drinking, resting, sleeping, performing bodily functions - as illegal because of where they occur (Donley \& Wright 2008). Criminalization entails aggressive police enforcement of quality of life ordinances that prohibit activities such as loitering or camping. Some ordinances target those who seek to help the homeless, cracking down on feeding programs and similar forms of assistance pursued out in the open. Intellectually, Vitale (2008) links the quality of life approach to "broken windows" logic about perceived neighborhood disorder and to the communitarian privileging of collective well-being over individual rights.

A few homeless advocates favor the approach, arguing that it could keep widespread homelessness from becoming a permanent (and acceptable) feature of the urban landscape. Most, however, claim that quality of life ordinances not only are impractical to implement but also persecute homeless people for lacking the privacy that domiciled individuals take for granted. Legal challenges to such ordinances, which stress the violation of civil and constitutional rights, have yielded mixed results, leaving case law on the matter unsettled (Stoner 1995). What does seem clear is that quality of life legislation and related mechanisms [police sweeps, forced removal, "greyhound therapy" (a one-way bus ticket to another city)] redistribute the homelessness problem across space rather than alleviating its causes.

Federal policy toward the homeless has also evolved since the early 1980s, when the Reagan administration denied the existence of the problem. The first comprehensive federal homelessness legislation, the Stuart B. McKinney Homeless Assistance Act (subsequently renamed the McKinney-Vento Act), was signed into law in 1987, with the goal of improving and increasing emergency services to homeless people. Initial McKinney-funded programs focused on food and shelter, outreach, primary health care, mental health treatment, addictions rehabilitation, and other forms of amelioration. Concern with more fundamental issues, such as education, jobs, and housing, was not prominently featured (Rosenthal \& Foscarinis 2006).

The growing federal interest in homelessness was accompanied by greater attention to program accountability, program evaluation, and cost-benefit analyses (Culhane et al. 2007). Implementation of the $\mathrm{CoC}$ model during the 1990s forced local service agencies to coordinate their efforts and minimize overlap as a precondition for federal funding. Indicative of this new efficiency emphasis, a HUD-sponsored national research symposium on homelessness addressed the theme "what works?" (Fosberg \& 
Dennis 1999). Among the summary papers presented at that symposium, however, only one examined permanent housing and employment as potential solutions to homelessness.

The most recent turn in national policy has been toward housing-first models and away from the alternative, services first. The housing-first approach seeks to move homeless individuals and families into permanent housing as quickly as possible (Locke et al. 2007). These placements are intended to be permanent and relatively free of restrictions. In most cases, wraparound services are part of the model but are not required. Housing-first recognizes housing as a fundamental right of citizenship. The model sharply contrasts with conventional thinking, i.e., that homeless people are somehow broken and must be repaired before they can be trusted to succeed in permanent housing. Early evaluations of housing-first interventions appear promising (Tsemberis et al. 2004).

\section{Conclusion}

An enduring legacy of the new homelessness literature reviewed here is its demonstration of the vital linkages possible between social science research and social policy. Studies conducted by Culhane and colleagues during the 1990s illustrate the point (see Culhane \& Metraux 2008). At odds with the then-prevalent imagery of homelessness as a permanent condition, Culhane's team showed that a small group of chronically homeless persons, representing about one-tenth of the total population, in fact consumed more than half of the daily shelter capacity. The policy implication was immediate: If permanent housing could be found for the chronic tenth, shelter capacity and its costs could be reduced by half.

Culhane's results were amplified by an emerging consensus in the sociological research community that homelessness is, fundamentally, a structural problem rooted in the larger political economy: too many poor people competing for too few low-income housing units. This structural understanding, combined with
Culhane's findings, has led to the rapid diffusion of housing-first approaches. Thanks to urging by the National Coalition to End Homelessness and the federal Interagency Council on Homelessness, more than 300 American cities have now adopted ten-year plans to end chronic homelessness, nearly all including some variation on housing-first. Such plans are consistent with what the literature reviewed here tells us about the effects of prolonged homelessness on material well-being, health, safety, and personal identity. In short, the symbiosis between research and policy that has developed in the two decades since the Shlay \& Rossi review has proved mutually enriching.

To sustain the research-policy relationship, social scientists should tackle a question that has inspired more conjecture than empirical analysis: how to prevent the occurrence of homelessness. Although the general answer is obvious-keeping people housed no matter how difficult their circumstances-the devil, as always, lies in the details. Guidance can be sought from the studies of macro- and microlevel causes cited above, which point to tight housing markets, individual risk factors (family conflict, a weak support network, etc.), and moments of heightened vulnerability (e.g., after release from an institution) as variables amenable to manipulation. Investigators might also learn something from the experiences of transitionally homeless persons, who are able to exit homelessness quickly and avoid reentry.

For prevention-oriented research to be compelling, however, it must have a strong comparative dimension. The comparison could take a cross-national form, especially if policy differences among countries are associated with different rates of homelessness. Even within the United States, prevention effects may be estimated for states, cities, families, and individuals systematically subjected (or not) to particular program interventions. Such comparative work will require the use of quasi-experimental designs, panel surveys, team ethnographies, and other methodological strategies that yield representative longitudinal data and that offer greater traction for disentangling outcomes 
from antecedents. If the political will to fund these expensive methods is forthcoming, sociologists could play a key role in the movement to prevent and, hopefully, eliminate the most serious types of homelessness.

\section{Summary Points}

1. Research since Shlay \& Rossi's (1992) review has distinguished among types of homelessness, finding the transitional (or temporary) type to be more common than its episodic or chronic counterparts.

2. Both point and period prevalence estimates document a national homeless population that is nontrivial in magnitude and thatwhile still dominated by single men-contains larger proportions of women, children, families, and minorities (especially African Americans) than in the past.

3. Homeless people suffer from reduced life chances, experiencing disadvantages in material well-being (e.g., income and benefits), physical and mental health, life expectancy, and personal safety.

4. Coping strategies employed by the homeless include shelter and service usage, wage labor, shadow work, reliance on social ties, identity management, and political mobilization and activism.

5. Support exists for an integrated macro/micro causal model in which the housing squeeze and other structural forces generate a population at risk of homelessness, with some members subsequently selected into a homeless state because of their personal vulnerabilities, institutional experiences, or lack of buffers.

6. Domiciled individuals' attitudes about homelessness vary by race, sex, political orientation, education, and degree of exposure, but their nuanced views are not simple reflections of how the media have covered the problem.
7. In contrast to an early emphasis on emergency services, federal policy is now geared toward rapid placement of the homeless in permanent housing, the elimination of chronic homelessness, and, ultimately, prevention.

8. Federal initiatives have been offset to some extent at the local level by NIMBY-fueled resistance to the decentralization of services and by the enactment of quality of life ordinances that criminalize homeless people's survival behaviors.

\section{Literature Cited}

Allgood S, Warren RS. 2003. The duration of homelessness: evidence from a national survey. J. Hous. Econ. 12:273-90

Anderson L, Snow DA, CressD. 1994. Negotiating the public realm: stigmamanagement and collective action among the homeless. In Research in Community Sociology: The Community of the Streets, ed. SE Cahill, LH Lofland, pp. 121-43. Greenwich, CT: JAI

Armaline WT. 2005. 'Kids need structure': negotiating rules, power, and social control in an emergency youth shelter. Am. Behav. Sci. 48:1124-48

Auerswald CL, Eyre SL. 2002. Youth homelessness in San Francisco: a life cycle approach. Soc. Sci. Med. 54:1497-512

Bahr HM, Caplow T. 1974. Old Men Drunk and Sober. New York: N. Y. Univ. Press

Bao WN, Whitbeck LB, Hoyt DR. 2000. Abuse, support, and depression among homeless and runaway adolescents. J. Health Soc. Behav. 41:408-20

Baron SW, Hartnagel TF. 1998. Street youth and criminal violence. J. Res. Crime Delinq. 35:166-92

Bassuk EL, Buckner JC, Weinreb LF, Browne A, Bassuk SS, et al. 1997. Homelessness in female-headed families: childhood and adult risk and protective factors. Am. J. Public Health 87:241-48 
Bassuk EL, Geller S. 2006. The role of housing and services in ending family homelessness. Hous. Policy Debate 17:781-806

Bassuk EL, Perloff JN, Dawson R. 2001. Multiply homeless families: the insidious impact of violence. Hous. Policy Debate 12:299-320

Blau J. 1992. The Visible Poor: Homelessness in the United States. New York: Oxford Univ. Press

Bogard CJ. 2003. Seasons Such as These: How Homelessness Took Shape in America. NewYork: Aldine deGruyter

Brinegar SJ. 2003. The social construction of homeless shelters in the Phoenix area. Urban Geogr. 24:61-74

Buck PO, Toro PA, Ramos MA. 2004. Media and professional interest in homelessness over 30 years (1974- 2003). Anal. Soc. Issues Public Policy 4:151-71

Bunis WK, Yancik A, Snow DA. 1996. The cultural patterning of sympathy toward the homeless and other victims of misfortune. Soc. Probl. 43:387-402

Burt MR. 1992. Over the Edge: The Growth of Homelessness in the 1980s. New York: Russell Sage Found.

Burt MR, Aron LY, Lee E, Valente J. 2001. Helping America's Homeless: Emergency Shelter or Affordable Housing? Washington, DC: Urban Inst. Press

Caton CLM, Dominguez B, Schanzer B, Hasin DS, Shrout PE, et al. 2005. Risk factors for longterm homelessness: findings from a longitudinal study of first-time homeless single adults. Am. J. Public Health 95:1753-59

Cohen A, Koegel P. 1996. The influence of alcohol and drug use on the subsistence adaptation of homeless mentally ill persons. J. Drug Issues 26:219-43

Cohen CI, RamirezM, Teresi J,GallagherM, Sokolovsky J. 1997. Predictors of becoming redomiciled among older homeless women. Gerontologist 37:67-74

Conroy SJ, Heer DM. 2003. Hidden Hispanic homelessness in Los Angeles: the 'Latino paradox' revisited. Hisp. J. Behav. Sci. 25:530-38

CraneM, Byrne K, Fu R, Lipmann B,Mirabelli F, et al. 2005. The causes of homelessness in later life: findings from a 3-nation study. J. Gerontol. B 60:S152-59

Cress DM, Snow DA. 1996. Mobilization at the margins: resources, benefactors, and the viability of homeless social movement organizations. Am. Sociol. Rev. 61:1089-109

CressDM, Snow DA. 2000. The outcomes of homelessmobilization: the influence of organization, disruption, political mediation, and framing. Am. J. Sociol. 105:1063-104

Croteau D, Hicks L. 2003. Coalition framing and the challenge of a consonant frame pyramid: the case of a collaborative response to homelessness. Soc. Probl. 50:251-72

Culhane DP, Dejowski EF, Ibanez J,Needham E,Macchia I. 1994. Public shelter admission rates in Philadelphia andNew York City: the implications of turnover for sheltered population counts. Hous. Policy Debate 5:107-40

Culhane DP, Gollub E, Kuhn R, Shpaner M. 2001. The co-occurrence of AIDS and homelessness: results from the integration of administrative databases for AIDS surveillance and public shelter utilization in Philadelphia. J. Epidemiol. Community Health 55:515-20

Culhane DP, Lee CM, Wachter SM. 1996. Where the homeless come from: a study of the prior address distribution of families admitted to public shelters in New York City and Philadelphia. Hous. Policy Debate 7:327-65

Culhane DP, Metraux S. 1999. One-year rates of public shelter utilization by race/ethnicity, age, sex and poverty status for New York City and Philadelphia. Popul. Res. Policy Rev. 18:219-36

Culhane DP, Metraux S. 2008. Rearranging the deck chairs or reallocating the lifeboats? Homeless assistance and its alternatives. J. Am. Plan. Assoc. 74:111-21

Culhane DP, Metraux S, Park JM, Schretzman M, Valente J. 2007. Testing a typology of family homelessness based on patterns of public shelter utilization in four U.S. jurisdictions: implications for policy and program planning. Hous. Policy Debate 18:1-28

Culhane DP, Parker W, Poppe B, Gross K, Sykes E. 2007. Accountability, cost-effectiveness, and program performance: progress since 1998. See Dennis et al. 2007, pp. 12-1-12-25 
Dachner N, Tarasuk V. 2002. Homeless 'squeegee kids': food insecurity and daily survival. Soc. Sci. Med. 54:1039-49

Dear M. 1992. Understanding and overcoming the NIMBY syndrome. J. Am. Plan. Assoc. 58:288-300

Dennis D, Locke G, Khadduri J, eds. 2007. Toward Understanding Homelessness: The 2007 National Symposium on Homelessness Research.Washington, DC: U.S. Dep. Health Hum. Serv., U.S. Dep. Hous. Urban Dev.

Dennis ML, Bray RM, Iachan R, Thornberry J. 1999. Drug use and homelessness. In Drug Use inMetropolitan America, ed. RM Bray, ME Marsden, 4:79-123. Thousand Oaks, CA: Sage

Dietz TL. 2007. Predictors of reported current and lifetime substance abuse problems among a national sample of U.S. homeless. Subst. Use Misuse 42:1745-66

Dietz TL, Wright JD. 2005. Age and gender differences and predictors of victimization of the older homeless. J. Elder Abuse Negl. 17:37-60

Donley AM, Wright JD. 2008. Cleaning up the streets: community efforts to combat homelessness by criminalizing homeless behaviors. In Homelessness in America, Vol. 3: Solutions to Homelessness, ed. RMcNamara, pp. 75-92. New York: Praeger

Dordick GA. 1997. Something Left to Lose: Personal Relations and Survival among New York's Homeless. Philadelphia, PA: Temple Univ. Press

Duneier M. 1999. Sidewalk. New York: Farrar, Straus \& Giroux

Dworsky AL, Piliavin I. 2000. Homeless spell exits and returns: substantive and methodological elaborations on recent studies. Soc. Serv. Rev. 74:193-213

Ennett ST, Bailey SL, Federman EB. 1999. Social network characteristics associated with risky behaviors among runaway and homeless youth. J. Health Soc. Behav. 40:63-78

Entner Wright BR. 1998. Behavioral intentions and opportunities among homeless individuals: a reinterpretation of the theory of reasoned action. Soc. Psychol. Q. 61:271-86

Entner Wright BR, Caspi A, Moffitt TE, Silva PA. 1998. Factors associated with doubled-up housing - a common precursor to homeless- ness. Soc. Serv. Rev. 72:92-111

Fertig AR, Reingold DA. 2008. Homelessness among at-risk families with children in twenty American cities. Soc. Serv. Rev. 82:485-510

Fitzpatrick KM, Irwin J, LaGoryM, Ritchey F. 2007. Just thinking about it: social capital and suicide ideation among homeless persons. J. Health Psychol. 12:750-60

Fitzpatrick KM, LaGoryME, Ritchey FJ. 1999. Dangerous places: exposure to violence and its mental health consequences for the homeless. Am. J. Orthopsychiatry 69:438-47

Fosberg LB, Dennis DL, eds. 1999. Practical Lessons: The 1998 National Symposium on Homelessness Research. Washington, DC: U.S. Dep. Hous. Urban Dev., U.S. Dep. Health Hum. Serv.

Foster H, Hagan J. 2007. Incarceration and intergenerational social exclusion. Soc. Probl. 54:399-433

Gaber SL. 1996. From NIMBY to fair share: the development of New York City's municipal shelter siting policies, 1980-1990. Urban Geogr. 17:294-316

Gowan T. 2002. The nexus: homelessness and incarceration in two American cities. Ethnography 3:500-34

Greenberg GA, Rosenheck RA. 2008. Jail incarceration, homelessness, and mental health: a national study. Psychiatr. Serv. 59:170-77

Grunberg J, Eagle PF. 1990. Shelterization: how the homeless adapt to shelter living. Hosp. Community Psychiatry 41:521-25

Haddad MB, Wilson TW, Ijaz K, Marks SM, Moore M. 2005. Tuberculosis and homelessness in the United States, 1994-2003. JAMA 293:2762-66

Hagan J, McCarthy B. 1998. Mean Streets: Youth Crime and Homelessness. Cambridge, UK: Cambridge Univ. Press

Hawkins RL, Abrams C. 2007. Disappearing acts: the social networks of formerly homeless individuals with co-occurring disorders. Soc. Sci. Med. 65:2031-42

Hewitt C. 1996. Estimating the number of homeless: media misrepresentation of an urban problem. J. Urban Aff. 18:431-47

Hopper K. 2003. Reckoning with Homelessness. Ithaca, NY: Cornell Univ. Press 
Hoyt DR, Ryan KR, Cauce AM. 1999. Personal victimization in a high-risk environment: evaluating the relative effects of exposure, attractiveness, and guardianship. J. Res. Crime Delinq. 36:371-92

Hwang SW, Lebow JM, Bierer MF, O'Connell JJ, Orav EJ, Brennan TA. 1998. Risk factors for death in homeless adults in Boston. Arch. Int. Med. 158:1454-60

Jasinski JL, Wesely JK, Wright JD, Mustaine E. 2010. Hard Lives, Mean Streets: The Experience of Violence in the Lives of Homeless Women. Boston: Univ. Press N. Engl.

Jencks C. 1994. The Homeless. Cambridge, MA: Harvard Univ. Press

Johnson KD, Whitbeck LB, Hoyt DR. 2005. Predictors of social network composition among homeless and runaway adolescents. J. Adolesc. 28:231-48

Karabanow J. 2008. Getting off the street: exploring the processes of young people's street exits. Am. Behav. Sci. 51:772-88

Kerr D, Dole C. 2005. Cracking the temp trap: day laborers' grievances and strategies for change in Cleveland, Ohio. Labor Stud. J. 29:87-108

Kidd SA. 2007. Youth homelessness and social stigma. J. Youth Adolesc. 36:291-99

KipkeMD, Simon TR, Montgomery SB, Unger JB, Iversen EF. 1997. Homeless youth and their exposure to and involvement in violence while living on the streets. J. Adolesc. Health 20:360-67

Knecht T, Martinez LM. 2009. Humanizing the homeless: does contact erode stereotypes? Soc. Sci. Res. 38:521-34

Koegel PM, Burnam A, Baumohl J. 1996. The causes of homelessness. In Homelessness in America, ed. J Baumohl, pp. 24-33. Phoenix, AZ: Oryx

Koegel P, Melamid E, Burnam MA. 1995. Childhood risk factors for homelessness among homeless adults. Am. J. Public Health 85:1642-49

Kushel MB, Vittinghoff E, Haas JS. 2001. Factors associated with the health care utilization of homeless persons. JAMA 285:200-6

LaGory M, Ritchey F, Fitzpatrick K. 1991. Homelessness and affiliation. Sociol. Q. 32:201-18

Lankenau SE. 1999a. Panhandling repertoires and routines for overcoming the nonperson treatment. Deviant Behav. 20:183-206

Lankenau SE. 1999b. Stronger than dirt: public humiliation and status enhancement among panhandlers. J. Contemp. Ethnogr. 28:288-318

Lee BA, Farrell CR. 2003. Buddy, can you spare a dime? Homelessness, panhandling, and the public. Urban Aff. Rev. 38:299-324

Lee BA, Farrell CR. 2005. The sheltered homeless in metropolitan neighborhoods: evidence from the 1990 and 2000 censuses. In Redefining Urban and Suburban America: Evidence from Census 2000, ed. A Berube, B Katz, RE Lang, 2:285-309. Washington, DC: Brookings Inst. Press

Lee BA, Farrell CR, Link BG. 2004. Revisiting the contact hypothesis: the case of public exposure to homelessness. Am. Sociol. Rev. 69:40-63

Lee BA, Greif MJ. 2008. Homelessness and hunger. J. Health Soc. Behav. 49:3-19

Lee BA, Link BG, Toro PA. 1991. Images of the homeless: public views and media messages. Hous. Policy Debate 2:649-82

Lee BA, Price-Spratlen T. 2004. The geography of homelessness in American communities: concentration or dispersion? City Community 3:3-27

Lee BA, Price-Spratlen T, Kanan JW. 2003. Determinants of homelessness in metropolitan areas. J. Urban Aff. 25:335-55

Lee BA, Schreck CJ. 2005. Danger on the streets: marginality and victimization among homeless people. Am. Behav. Sci. 48:1055-81

Liebow E. 1993. Tell Them Who I Am: The Lives of Homeless Women. New York: Penguin

Link BG, Phelan J, Bresnahan M, Stueve A, Moore RE, Susser E. 1995a. Lifetime and five-year prevalence of homelessness in the United States: new evidence on an old debate. Am. J. Orthopsychiatry 65:347-54

Link BG, Schwartz S,Moore RE, Phelan J, Struening E, et al. 1995b. Public knowledge, attitudes, and beliefs about homeless people: evidence for compassion fatigue? Am. J. Community Psychol. 23:533-55

Locke G, Khadduri J, O'Hara A. 2007. Housing models. See Dennis et al. 2007, pp. 10-1-10-30

Marcus A. 2003. Shelterization revisited: some 
methodological dangers of institutional studies of the homeless. Hum. Organ. 62:134-42

McCarthy B, Hagan J. 2005. Danger and the decision to offend. Soc. Forces 83:1065-96

Metraux S, Culhane DP. 1999. Family dynamics, housing, and recurring homelessness among women inNew York City shelters. J. Fam. Issues 20:371-96

Metraux S, Roman CG, Cho RS. 2007. Incarceration and homelessness. See Dennis et al. 2007, pp. 9-1-9-31

Molina E. 2000. Informal nonkin networks among homeless Latino and African American men. Am. Behav. Sci. 43:663-85

Myers D, Wolch JR. 1995. The polarization of housing status. In State of the Union: America in the 1990s. Vol. 1: Economic Trends, ed. R Farley, pp. 269-334. New York: Russell Sage Found.

Oakley D. 2002. Housing homeless people: local mobilization of federal resources to fight NIMBYism. J. Urban Aff. 24:97-116

O'Connell JJ. 2005. Premature Mortality in Homeless Populations: A Review of the Literature. Nashville, TN: Natl. Health Care Homeless Counc.

O'Flaherty B. 1996. Making Room: The Economics of Homelessness. Cambridge, MA: Harvard Univ. Press

O'Flaherty B. 2003. Need and generosity: how markets for free goods equilibrate. J. Urban Econ. 54:157-72

O'Flaherty B. 2004. Wrong person or wrong place: for homelessness, the conjunction is what matters. J. Hous. Econ. 13:1-15

Park JYS. 2000. Increased homelessness and low rent housing vacancy rates. J. Hous. Econ. 9:76-103

Pascale CM. 2005. There's no place like home: the discursive creation of homelessness. Cult. Stud./Crit. Methodol. 5:250-68

Pecora PJ, Kessler RC,O'Brien K, White CR, Williams J, et al. 2006. Educational and employment outcomes of adults formerly placed in foster care: results from the Northwest Foster Care Alumni Study. Child. Youth Serv. Rev. 28:1459-81

Phelan J, Link BG,Moore RE, Stueve A. 1997. The stigma of homelessness: the impact of the label 'homeless' on attitudes toward poor persons. Soc. Psychol. Q. 60:323-37

Phelan J, Link BG, Stueve A, Moore RE. 1995. Education, social liberalism, and economic conservatism: attitudes toward homeless people. Am. Sociol. Rev. 60:126-40

Piliavin I, Entner Wright BR, Mare RD, Westerfelt AH. 1996. Exits from and returns to homelessness. Soc. Serv. Rev. 70:33-57

Quigley JM, Raphael S, Smolensky E. 2001. Homeless in America, homeless in California. Rev. Econ. Stat. 83:37-51

Rafferty Y, Shinn B, Weitzman BC. 2004. Academic achievement among formerly homeless adolescents and their continuously housed peers. J. Sch. Psychol. 42:179-99

Reardon ML, Burns AB, Preist R, Sachs-Ericsson N, Lang AR. 2003. Alcohol use and other psychiatric disorders in the formerly homeless and never homeless: prevalence, age of onset, comorbidity, temporal sequencing, and service utilization. Subst. Use Misuse 38:601-44

Rice E, Milburn NG, Rotheram-Borus MJ, Mallett S, Rosenthal D. 2005. The effects of peer group network properties on drug use among homeless youth. Am. Behav. Sci. 48:1102-23

Ringwalt CL, Greene JM, Robertson M, McPheeters M. 1998. The prevalence of homelessness among adolescents in the United States. Am. J. Public Health 88:1325-29

Robertson M, Harris N, Fritz N, Nofsinger R, Fischer P. 2007. Rural homelessness. See Dennis et al. 2007, pp. 8-1-8-32

Roman CG, Travis J. 2006. Where will I sleep tomorrow? Housing, homelessness, and the returning prisoner. Hous. Policy Debate 17:389-418

Roschelle AR, Kaufman P. 2004. Fitting in and fighting back: stigma management strategies among homeless kids. Symb. Interact. 27:23-46

Rosenthal R. 1994. Homeless in Paradise: A Map of the Terrain. Philadelphia, PA: Temple Univ. Press

Rosenthal R, Foscarinis M. 2006. Responses to homelessness: past policies, future directions, and a right to housing. In A Right to Housing: Foundation for a New Social Agenda, ed. RG Bratt, ME Stone, C Hartman, pp. 316-39. Philadelphia, PA: Temple Univ. Press 
Rossi PH. 1989. Down and Out in America: The Origins of Homelessness. Chicago: Univ. Chicago Press

Sager R, Stephens LS. 2005. Serving up sermons: clients' reactions to religious elements at congregation-run feeding establishments. Nonprofit Volunt. Sect. Q. 34:297-315

Salamon S, MacTavish K. 2006. Quasi-homelessness among rural trailer-park households in the United States. In International Perspectives on Rural Homelessness, ed. P Milbourne, P Cloke, pp. 45-62. London: Routledge

Shields TG. 2001. Network news construction of homelessness: 1980-1993. Commun. Rev. 4:193-218

Shinn M, Gottlieb J, Wett JL, Bahl A, Cohen A, Ellis DB. 2007. Predictors of homelessness among older adults in New York City. J. Health Psychol. 12:696-708

Shinn M, Knickman JR, Weitzman BC. 1991. Social relationships and vulnerability to becoming homeless among poor families. Am. Psychol. 46:1180-87

Shlay AB, Rossi PH. 1992. Social science research and contemporary studies of homelessness. Annu. Rev. Sociol. 18:129-60

Smith H. 2008. Searching for kin: the creation of street families among homeless youth. Am. Behav. Sci. 51:756-71

Snow DA, Anderson L. 1993. Down on Their Luck: A Study of Homeless Street People. Berkeley: Univ. Calif. Press

Snow DA, Mulcahy M. 2001. Space, politics, and the survival strategies of the homeless. Am. Behav. Sci. 45:149-69

Snow DA, Soule SA, Cress DM. 2005. Identifying the precipitants of homeless protest across 17 U.S. cities, 1980 to 1990. Soc. Forces 83:1183-210

Spencer WJ. 1996. From bums to the homeless: media constructions of persons without homes 1980-1984. In Perspectives on Social Problems, ed. JA Holstein, G Miller, 8:39-58. Greenwich, CT: JAI

Stoner MR. 1995. The Civil Rights of Homeless People: Law, Social Policy, and Social Work Practice. New York: Aldine de Gruyter

Szerlip MI, Szerlip HM. 2002. Identification of car- diovascular risk factors in homeless adults. Am. J. Med. Sci. 324:243-46

Takahashi LM. 1998. Homelessness, AIDS, and Stigmatization: The NIMBY Syndrome in the United States at the End of the Twentieth Century. Oxford: Clarendon

Tessler R, Rosenheck R, Gamache G. 2003. Homeless veterans of the all-volunteer force: a social selection perspective. Armed Forces Soc. 29:509-24

Toohey SM, Shinn M, Weitzman BC. 2004. Social networks and homelessness among women heads of household. Am. J. Community Psychol. 33:7-20

Toro PA,McDonell DM. 1992. Beliefs, attitudes, and knowledge about homelessness: a survey of the general public. Am. J. Community Psychol. 20:53-80

Toro PA, Tompsett CJ, Lombardo S, Philippot P, Nachtergael H, et al. 2007. Homelessness in Europe and the United States: a comparison of prevalence and public opinion. J. Soc. Issues 63:505-24

Tsemberis S, Gulcur L, Nakae M. 2004. Housing first, consumer choice, and harm reduction for individuals who are homeless with dual diagnoses: a 24-month clinical trial. Am. J. Public Health 94:651-56

Tyler KA. 2006. A qualitative study of early family histories and transitions of homeless youth. J. Interpers. Violence 21:1385-93

Tyler KA. 2008. Social network characteristics and risky sexual and drug-related behaviors among homeless young adults. Soc. Sci. Res. 37:673-85

Tyler KA, Hoyt DR, Whitbeck LB, Cauce AM. 2001. The impact of childhood sexual abuse on later sexual victimization among runaway youth. J. Res. Adolesc. 11:151-76

Tyler KA, Johnson KA. 2004. Victims and offenders: accounts of paybacks, invulnerability, and financial gain among homeless youth. Deviant Behav. 25:427-49

Tyler KA, Whitbeck LB, Hoyt DR, Cauce AM. 2004. Risk factors for sexual victimization among male and female homeless and runaway youth. J. Interpers. Violence 19:503-20

U.S. Dep. Hous. Urban Dev. (U.S. HUD). 2009. The 2008 Annual Homeless Assessment Report to Con- 
gress. Washington, DC: Off. Community Plan. Dev.

Vitale AS. 2008. City of Disorder: How the Quality of Life Campaign Transformed New York Politics. New York: N. Y. Univ. Press

Wagner D. 1993. Checkerboard Square: Culture and Resistance in a Homeless Community. Boulder, CO:Westview

Wagner D, Cohen MB. 1991. The power of the people: homeless protesters in the aftermath of social movement participation. Soc. Probl. 38:543-61

Wakin M. 2005. Not sheltered, not homeless: RVs as makeshifts. Am. Behav. Sci. 48:1013-32

Wenzel SL, Leake BD, Gelberg L. 2001. Risk factors for major violence among homeless women. Am. Behav. Sci. 45:14-34

Whitbeck LB, Hoyt DR. 1999. Nowhere to Grow: Homeless and Runaway Adolescents and Their Families. New York: Aldine de Gruyter

Williams JC. 2003. A Roof Over My Head: Homeless Women and the Shelter Industry. Boulder: Univ. Colo. Press

Wong YI. 1997. Patterns of homelessness: a review of longitudinal studies. In Understanding Homelessness: New Policy and Research Perspectives, ed. DP Culhane, SP Hornburg, pp. 135-64. Washington, DC: Fannie Mae Found.

Wong YI, Piliavin I. 1997. A dynamic analysis of homeless-domicile transitions. Soc. Probl. 44:408-23

Wright JD. 1990. Poor people, poor health: the health status of the homeless. J. Soc. Issues 46:49-64

Wright JD, Devine JA. 1992. Counting the homeless: the Census Bureau's 'S-night' in five US cities. Eval. Rev. 16:355-64

Wright JD, Devine JA. 1995. Housing dynamics of the homeless: implications for a count. Am. J. Orthopsychiatry 65:320-33

Wright JD, Donley AM, Gotham KF. 2008. Housing policy, the low income housing crisis, and the problem of homelessness. In Homelessness in America, Vol. 2, Causes of Homelessness, ed. R McNamara, pp. 31-48. New York: Praeger
Wright JD, Rubin BA, Devine JA. 1998. Beside the Golden Door: Policy, Politics, and the Homeless. New York: Aldine de Gruyter

Wright T. 1997. Out of Place: Homeless Mobilizations, Subcities, and Contested Landscapes. Albany: State Univ. N. Y. Press

Yoder KA, Whitbeck LB, Hoyt DR. 2001. Event history analysis of antecedents to running away from home and being on the street. Am. Behav. Sci. 45:51-65

Zima BT, Bussing R, Forness SR, Benjamin B. 1997. Sheltered homeless children: their eligibility and unmet need for special education evaluations. Am. J. Public Health 87:236-40

\section{Related Resources}

Henslin JM. 1993. Homelessness: An Annotated Bibliography, Vols. I, II. New York: Garland

Levinson D, ed. 2004. Encyclopedia of Homelessness, Vols. I, II. Thousand Oaks, CA: Sage

McNamara R, ed. 2008. Homelessness in America, Vols. 1-3. Westport, CT: Praeger

\section{Web sites for federal government agencies:}

Interagency Council on Homelessness: http://www.ich.gov

Substance Abuse and Mental Health Services Administration Resource Center: http://homelessness.samhsa.gov

Web sites for advocacy organizations (with links to fact sheets, reports, and bibliographies):

National Alliance to End Homelessness: http://www.endhomelessness.org

National Coalition for the Homeless: http://www.nationalhomeless.org

National Law Center on Poverty and Homelessness: http://www.nlchp.org 